\title{
VIDA E TEATRO EM GUIMARÃES ROSA: GRANDE SERTÃO: VEREDAS E PIRLIMPSIQUICE
}

\author{
Mário Fernando BOLOGNESI*
}

\begin{abstract}
RESUMO: Este artigo inicia-se com uma exposição sucinta da metáfora do teatro, tal como aparece em Platão. Em seguida, após levantamento dos momentos capitais da literatura, investiga-se a metáfora em Guimarães Rosa, no Grande sertão: veredas e no conto Pirlimpsiquice. No Grande sertão, $a$ atuação no palco é tomada como equivalente ao desempenho na vida. Teatro e vida são, portanto, domínios que se identificam. Para isto, concorrem a religião cristã e o pensamento de Plotino. Em Pirlimpsiquice, o Autor investiga pormenorizadamente os limites e aproximações entre teatro $e$ vida, sendo que o grau mínimo da metáfora é conferido pelas práticas histórica e cultural. Por fim, retomando a polêmica de Hegel com o platonismo, conclui-se que a representação e a vida estão amalgamadas, numa constante dialetização entre história e cultura.
\end{abstract}

UNITERMOS: Literatura; teatro; teoria de teatro; literatura brasileira.

1. Desde os primórdios do universo cultural do Ocidente, a vida comparada ao teatro vem assumindo lugar significativo nos mais diversos domínios da cultura. Dentre estes, cumpre assinalar que no âmbito da produção literária o uso deste recurso metafórico é constante e de ampla significação (1). O aparecimento da metáfora teatral na tradição escrita ocidental se dá já na Grécia antiga e, com Platão, ela adquire um sustentáculo precioso em termos de um estatuto filosófico de maior envergadura e complexidade.

A metáfora đo teatro pode ser apreciada, em Platão, a partir da alegoria da caverna. Nesta, alguns prisioneiros contemplam sombras projetadas e escutam sons confusos, cuja origem desconhecem, tomando, assim, por realidade o que é apenas ilusório.

Muito embora o contexto original da alegoria se refira à educação e ao conhecimento ideais, livres da matéria e dos sentidos, rumo ao esplendor das essências, a situação dos prisioneiros face às sombras é bastante próxima do teatro. Esta proximidade pode ser vista desde os aspectos técnicos de distribuição e organização dos elementos constitutivos da alegoria (prisioneiros, objetos, foco de luz, sombra etc.), como também no que se refere a aspectos de ordem teórica.

Quanto aos aspectos técnicos, o próprio autor se utiliza de um tipo de teatro para fazer a descrição da alegoria: refere-se aos “exibidores de fantoches”" para melhor explicar a situação e sujeição dos escravos no interior da caverna (7 - VII, 514. $\left.{ }^{\mathrm{a}}-515 .^{\mathrm{a}}\right)$.

Os aspectos de ordem teórica, por sua vez, podem ser identificados sob os laços de uma possível teoria da representação. Esta, com ef eito, identifica-se com o interior da caverna, onde os prisioneiros têm contato apenas com as aparências, jamais com os ob-

\footnotetext{
* Departamento de Filosofia - Faculdade de Educação, Filosofia, Ciências Sociais e da Documentação - UNESP 17500 - Marilia - SP.
} 
jetos e as coisas mesmas. Ou seja, os escravos, ao contemplarem as sombras projetadas, tomam por realidade o que é apenas uma imagem. O mundo das ilusões, que é o da caverna, por inferência passa a ser o dos homens, na medida em que são submissos aos sentidos e às aparências. Em última palavra, neste mundo, segundo Platão, os homens estão aprisionados às imagens e representações dos objetos e coisas. Ao tomar o ilusório como real, os prisioneiros da caverna são vítimas de um modo concreto de representação - o de projeção, gerador de sombras - , modo este que produz simulacros e falsificações.

Por fim, é bastante conhecido o desprezo de Platão para com as artes, os poetas e o teatro. Em sua comunidade perfeita os poetas são banidos, pois a arte que professam não passa de imitação, de reprodução da imagem de um objeto, que vem a ser, por seu turno, simples cópia de uma idéia. Para Platão, o prazer, o riso e a dor, próprios da poesia e das artes, são atributos contrários à lei da razão que deve orientar a cidade perfeita. Em poucas palavras, os poetas são forjadores de fantasias e enganosidades. A única tolerância do Estado platônico diz respeito aos "hinos em honra dos deuses e os elogios à gente de bem"' $\left(7-\mathrm{X}, 607 .^{\mathrm{a}}\right)$.

2. No âmbito estrito da produção literária, o teatro e os seus principais motivos são encontrados nos mais diversos autores e períodos. Um momento expressivo de desdobramento e condensação da metáfora em questão pode ser encontrado no Renascimento e Barroco. Tanto na Espanha, como na Itália ou Inglaterra, do final da Idade Média em diante, o teatro e suas questões substanciais tomam conta da literatura. Apenas a título de exemplificação, podem ser assinaladas as seguintes obras: La divina commedia, de Dante Alighieri; Hamlet, de William Shakespeare; El ingenioso hidalgo Don Quijote de La Mancha, de Miguel de Cervantes Saavedra; ou ainda, no Século de Ouro espanhol, El gran teatro del mundo, de Calderón de La Barca.

Mais próximos da contemporaneidade, os românticos franceses e alemães fazem da metáfora do teatro um dos pontos centrais de seus ideários, recuperando o sentido ilusório e enganoso da existência humana, sendo a vida em sociedade o grande palco da opressão, da transitoriedade e das ilusões. Ainda no século XIX, em pleno Realismo, Stendhal e Balzac também comparam a vida ao teatro.

Por estar inserido de forma orgânica na sociedade européia do século passado, o teatro e sua prática cultural são utilizados por Marcel Proust como metáforas da organização social. Proust faz uso do teatro para uma possível crítica

tica, onde o espaço teatral aparece como local privilegiado de reprodução das estruturas sociais. Com isso, o teatro passa a ser o grande depositário mitológico daquela época, local que deixa transparecer a convivência e os conflitos sociais aristocráticos.

É também particularmente interessante a aparição deste incansável motivo metafórico na literatura brasileira. José de Alencar, Aluízio de Azevedo, Bernardo Guimarães e Lima Barreto são autores que trazem para dentro de suas ficções a vida comparada ao teatro, às vezes até mesmo com caráter sensível de perda e substituição da primeira em detrimento do segundo.

Em Machado de Assis, o motivo do teatro aparece com assídua freqüência. Em praticamente todas as situações ele desponta como um convívio social, um local de reposição dos costumes dos cidadãos em busca de uma identificação coletiva. A ópera, em Dom Casmurro, por exemplo, assume destaque especial, e, a partir dela, o Brasil do século XIX pode ser expresso. Machado de Assis chega a compor uma teoria da ópera, onde Deus é o poeta; Satanás, o músico; a terra, o palco; e os habitantes, a companhia (6, Cap. IX). 
BOLOGNESı, M.F. - Vida e teatro em Guimarães Rosa: Grande sertão veredas e Pirlimpsiquice.

Trans/Form/Ação, São Paulo, 8:49-60, 1985.

Rastreando os momentos culminantes da literatura e da filosofia, talvez com a preocupação de tornar presente em sua obra um tema que é encontrado nos mais significativos momentos culturais e literários, Guimarães Rosa também se apropria do teatro como imagem da vida. Mas, ao fazer uso deste procedimento já solidificado pela tradição, o autor de Grande sertão: veredas o introduz na realidade do sertão, em sua história, portanto. Ao fazê-lo, revela que a vida e o teatro se auto-refletem, sendo, ao mesmo tempo, componentes necessários um ao outro. São, em última instância, para Guimarães Rosa, dois elementos que se amalgamam em um só complexo.

3. Em Guimarães Rosa, o teatro se faz metáfora em dois momentos de sua obra: Grande sertão: veredas e no conto Pirlimpsiquice, do volume Primeiras estórias.

No decorrer do Grande sertão, referências ao teatro e aos diversos temas e motivos que ele comporta são encontradas sob diversos aspectos. Uma vez reunidas em torno de suas principais manifestações, têm-se as seguintes formas de aparição:

a) Mascaramento: personagens e suas ações são tomadas como mascaramento de uma identidade ulterior. Logo de início, este mascaramento é identificado como manifestação do demônio em seus infinitos aparecimentos na obra (2);

b) Metamorfose: transformações repentinas de intenção e comportamento levam à comparação com a metamorfose do ator, a partir de um pequeno olhar no espelho (8,p. 38);

c) Representação: a disposição e movimentação das personagens se assemelham à representação circense ou teatral $(8$, p. $100 ; 195 ; 201 ; 276 ; 344)$;

d) “Teatrar'”: em uma das infinitas transformações operadas por Guimarães Rosa na linguagem, encontra-se a conjugação do verbo "teatrar'” (8,p. 123);

e) Sala de teatro: tomado de desejo pelo corpo de Diadorim, Riobaldo quer estar na sala de teatro (8,p. 140);

f) Mamulengo: um espantalho é tido como “mamolengo" (8,p.370).

No entanto, do ponto de vista de uma teorização da metáfora teatral, a mais fecunda forma de aparição do teatro, no Grande sertão: veredas, diz respeito à clássica comparação com a vida.

Não se trata, aqui, de percorrer todas as referências encontradas, conforme enumeração acima, mas apenas de tomar a metáfora do teatro na relevância específica da concepção de Guimarães Rosa. Trata-se, pois, de rastrear a conformação temática da vida comparada ao teatro, de forma a detectar e esclarecer alguns eixos conceituais mínimos que são utilizados pelo Autor em sua tomada do teatro como motivo ficcional para exemplificar a vida.

Ainda que a bibliografia crítica rosiana seja das mais amplas, são esparsos os momentos em que se encontra uma análise mais detalhada dos motivos teatrais. Notam-se apenas algumas referências rápidas, como a indicarem que o assunto não passou desapercebido, sem que, no entanto, tenham merecido a devida atenção. Para Guimarães Rosa e o Grande sertão: veredas em particular, falar do teatro é abrir a reflexão para os mais diversos âmbitos do pensamento e adentrar às questões da filosofia, da psicologia e religião. Fazendo uso de procedimentos sintéticos globais, Guimarães concretiza, nos domínios da cultura e da realidade presentes na obra, proposições encontradas em autores diversos, de influências várias, em momentos históricos díspares.

4. Como ponto de partida para a análise aqui proposta, faz-se necessário situar o Grande sertão e o conto Pirlimpsiquice no conjunto da obra de Guimarães Rosa. Ou seja, ainda a título preliminar, na ótica explícita de uma ordenação poética, na opinião de Lenira Marques Covizzi, as obras aqui analisadas são de naturezas distintas. 
BOLOGNESI, M.F. - Vida e teatro em Guimarães Rosa: Grande sertão veredas e Pirlimpsiquice. Trans/Form/Ação, São Paulo, 8:49-60, 1985.

Segundo Lenira, em sua obra $O$ insólito em Guimarães Rosa e Borges, o trajeto poético de Guimarães parte da expressão e caminha para a explicação. Para o primeiro desses momentos - o da expressão - corresponde o trabalho do produtor literário. $\mathrm{O}$ segundo - da explicação - , é o momento metalingüístico do autor, ou seja, é o espaço privilegiado de preocupação com sua própria poética, ainda que esta se dê sob a forma de ficção. Lenira, inclusive, demarca esse limite a partir de Primeiras estórias:

“Depois de Grande sertão: veredas e Corpo de Baile, Guimarães Rosa só fez reescrevê-los didaticamente através de pílulas narrativas, operando uma diluição da visão do mundo, expressa naquelas obras."' $(4$, p.60).

Ou ainda:

"Primeiras estórias, por paradoxal que isso possa parecer, è o inicio de uma poética e philosophica. Guimarães Rosa, na sua vida ficcional, segue uma linha que já definimos acima como sendo aquela que vai da expressão à explicação. E, a nosso ver, a explicação no seu caráter de lógica e clareza se inicia com estas Primeiras estórias. (...) Uma ficção que sempre quis ser, busca, procura, se esclarece a si mesma, atribuindo-se o direito de responder ao processo que a gerou'. (4,p. 61).

Não se trata, aqui, de confirmar ou rejeitar, no todo, a tese de Lenira Marques Covizzi. Este trabalho se apropria de tal tese, procurando aplicá-la para a abordagem das referências ao teatro, tal como aparecem no Grande sertão: veredas e, posteriormente, em Pirlimpsiquice.

5. Para a compreensão do amalgamento que Guimarães Rosa promove entre os domínios da vida e do teatro, sob a ótica da introdução da metáfora do teatro na realidade do sertão, tal como descrita em sua obra capital, o Grande sertão, faz-se necessário ressaltar a importância da narrativa nesta conjunção dos domínios da história e da cultura.

A narração em terceira pessoa de Guimarães Rosa não se exime do envolvimento próprio da primeira, totalmente facilitado em virtude do personagem-narrador fazer constante uso da memória, da reflexão e da intuição. De acordo com Lenira Marques Covizzi, em seu trabalho já citado, O insólito em Guimarães Rosa e Borges:

"A terceira pessoa rosiana, num movimento contrário, é sempre envolvente por alguma razão. É muito difícil determinar os limites entre narrador e narrativa porque não existe entre eles uma distância crítica'”. (4,p. 74).

Riobaldo não só se recorda dos acontecimentos passados, como também, ao fazêlo, permeia-os de comentários presentes. Nesta inserção do passado no presente, na revivescência crítico-reflexiva portanto, os tempos histórico e mitológico se fundem, sendo quase sempre impossível se estabelecer fronteiras para esta dualidade. Mito, pensamento e história estão todo o tempo presentes em uma narrativa que tem como material básico, o passado. A esse respeito, Álvaro Martins Andrade, em sua tese de doutoramento, Universo, processo e ética no "Grande sertão: veredas", diz o seguinte:

O narrador não está (...) refletindo, criticando e meditando um passado encerrado, mas assume mover-se dentro dele como um presente (...)'. (1,p. 90).

Por este processo de conjunção, Guimarães Rosa consegue inserir o homem em sua cultura e em sua história. Os dados mitológicos e os do pensamento se solidificam em Riobaldo, nos acontecimentos da jagunçagem. Nesta dinâmica, a história e a cultura se cristalizam na subjetividade do narrador. Uma subjetividade, entretanto, que é dada como estado de consciência do jagunço já velho e barranqueiro. É nesse movimento uno, do passado feito presente, e deste feito consciência, que a narrativa faz uso das 
primeira e terceira pessoas, para instaurar, assim, um outro domínio - também uno - entre memória, reflexão e intuição. Memória, para recuperação histórica; ref.lexão, para exercício da razão consciente do ex-chefe de jagunços; intuição, para a inserção, na narrativa, dos domínios mítico-religiosos.

A unidade dos tempos histórico e mitológico faz com que a cultura se encontre no real, ou seja, se mescle à história. Assim, o universo das representações e a vida representada não estão dissociados, e qualquer tentativa de análise que promova essa dissociação corre o risco de instaurar um abstracionismo desprovido de localização. Se há metafísica no Grande sertão, ela está inserida em um tempo e espaço próprios e reais. Ou ainda, como se refere Antonio Cândido, a este propósito, em sua obra Tese $e$ antitese,

“E nós podemos ver que o real é ininteligível sem o fantástico, e que ao mesmo tempo este é o caminho para o real. Nesta grande obra (Grande sertão: veredas) combinam-se o mito e o logos, o mundo da fabulação lendária e o da interpretação racional, que disputam a mente de Riobaldo, nutrem a sua introspecção tacteante e extravasam sobre o Sertão', (3, p. 139, grifos nossos).

6. A metáfora do teatro, ou para utilizar a própria expressão do autor, o "teatral do mundo' (8, p. 276), obedece ao mesmo processo de entrelaçamento, tal como analisado. Mundo e teatro não despontam como instâncias distintas. Pode-se ler o primeiro como vida e história, e o segundo como cultura e representação. Assim concebendo, não há para Guimarães substituição da vida pela representação, nem da essência pela aparência. Na dialetização desses domínios, a essência sempre aparece e o aparente é o essencial. A identificação da vida com o teatro se dá nos seguintes termos:

"Vida devia de ser como na sala do teatro, cada um inteiro fazendo com forte gosto seu papel, desempenho', (8, p. 187).

O desempenho sincero e fecundo de um ator na representação teatral é tomado como exemplo para um mesmo desempenho sincero e fecundo na vida.

Este ponto de vista é bastante distinto da visão platônica, tal como vista no item 1 . Platão estabelece distinções claras e explícitas entre o mundo das aparências e ilusões, e o mundo perf eito das essências e das idéias. A representação artística, para o platonismo, não se livra da imitação desajustada e imperfeita dos objetos, sendo, portanto, mera cópia de uma idéia.

Guimarães Rosa, por sua vez, considera uma adequação entre o essencial e sua aparência, identificando a vida com o teatro. Com isso, distancia-se da concepção substitutiva - e até depreciativa - do teatro pela vida, tal como aparecem, por exemplo, em Platão e em certas concepções do Barroco (3).

7. Um dos raros momentos da crítica literária que atenta para a presença da metáfora teatral em Guimarães, é encontrado em Suzi Frankl Sperber, em seu estudo, Caos $e$ cosmos: leituras de Guimarães Rosa. Ao investigar a biblioteca particular do Autor em estudo, Sperber procura, pelo método comparativo, vincular as leituras do escritor à sua própria ficção. Para o que se refere ao teatro, destacou a obra de Plotino, Ennéades:

“Em um dos textos sublinhados por Guimarães Rosa é definido o “teatral” como sendo conseqüência da ação inconsciente do homem exterior, do homem não filosófico(...).

"Já em outro texto, quase que imediatamente posterior, também sublinhado por Guimarães Rosa, não é a inconsciência que produz atos que se parecem com os da cena teatral, senão, pelo contrário, a consciência, a razão, que propicia uma sin- 
cronização, e um domínio dos atos, de modo a dar-lhes forma' (12, p. 104).

Se o desempenho em si é tido como sincero e fecundo, pode-se vê-lo como conseqüência de uma ação inconsciente que propulsiona o homem a "dar corpo ao suceder'". Mas, ao mesmo tempo, é exatamente esta "gã que empurrava a gente para fazer tantos atos, dar corpo ao suceder”' (8, p. 79) que Riobaldo procura compreender, através de sua narração. Este impulso inconsciente, que se faz desempenho social - e também teatral - , é a própria organização da realidade que se apresenta informe. Na ordenação do papel “com forte gosto”' (8, p. 187) se presencia a ação organizadora do real caótico, em um movimento duplo entre razão e não-razão, consciência e impulso inconsciente. Neste movimento, vislumbram-se os momentos em que se é apenas personagem (no caso, desempenho impulsivo), e outros em que se cristaliza a própria consciência do desempenho. Esta consciência se dá pelo fato de o desempenho, no teatro, ser previsto e organizado de antemão. Assim, a vida - como o teatro - traz conjuntamente essas ações consciente e inconsciente.

Mas, como ressalta Sperber, Guimarães Rosa associa às idéias de Plotino o pensamento bíblico, mesclando religião e filosofia. O elemento religioso é introduzido pela admissão de uma lei escondida da verdadeira vida: a predestinação humana, que aparece no Grande sertão sob os seguintes termos:

"A que era: que existe uma receita, a norma dum caminho certo, estreito, de cada uma pessoa viver - e essa pauta cada um tem - mas a gente mesmo, no comum, não sabe encontrar; como é que, sozinho, por si, alguém ia poder encontrar e saber? Mas esse norteado, tem. Tem que ter. Se não, a vida de todos ficava sendo sempre o conf uso dessa doideira que é. E que: para cada dia, e cada hora, só uma ação possível da gente é que consegue ser a certa. Aquilo está no encoberto; mas, fora dessa conseqüência, tudo o que eu fizer, o que o senhor fizer, ou deixar de fazer, fica sendo falso, e é o errado. Ah, porque aquela outra é a lei, escondida e visível mas não achável, do verdadeiro viver: que para cada pessoa, sua continuação, já foi projetada, como o que se põe, em teatro, para cada representador sua parte, que antes já foi inventada, num papel (...)' (8, p. 366, grifos nossos).

O sentido da criação divina da vida é comparado ao texto de teatro, onde os papéis estão previamente estabelecidos. Deste modo, Deus é comparável ao autor teatral aquele que traça o rumo das personagens; por analogia, aquele que estabelece o destino humano. A organização da realidade caótica se define à semelhança da estrutura teatral, com os atores e seus papéis. Os papéis, por sua vez, correspondem a uma criação superior.

Com muita facilidade, o texto acima citado pode ser interpretado de acordo com os preceitos platônicos da alegoria da caverna. Nesse sentido, a vida projetada como no teatro, não alcança, ao nível do idealismo, o verdadeiro viver, o absoluto, que de forma alguma é perceptível na realidade imediata. Esta é, aliás, a interpretação de Suzi Frankl Sperber. A autora, com ef eito, faz corresponder a desordenação do mundo com a confusão da caverna, opondo, portanto, uma realidade superior, ideal e absoluta, a uma realidade informe, somente atingível com a intuição imediata. De acordo com suas palavras,

"Os movimentos desencontrados do mundo, no mundo, corresponderiam à penumbra e confusão da caverna. Os papéis corresponderiam a uma norma superior. Foram criados para a representação na vida. Criados por quem? Por uma entidade superior: Deus. O verdadeiro viver, o certo, existe, mas em um mundo que é praticamente ideal - porque desconhecido - e porque não perceptível na 
realidade imediata. Para o conhecimento desta realidade superior - ideal - absoluta-serve apenas a intuição imediata somada ao contacto inefável' '.(12, p. 106)

Esta interpretação desconsidera, em primeiro lugar, a configuração do relacionamento, para Plotino, entre arte e essência. Plotino ultrapassa o mestre Platão, e considera a arte como uma possibilidade de desvelamento da essência. "Ele mostrará contra Platão que a obra de arte não é a imitação do sensível, mas desvelamento da essência, mais imediata e mais fundamental que toda manifestação sensível' (2, p. 205). Assim, a arte - por decorrência, também o teatro - deixa de ser tomada como cópia e se circunscreve no rumo das atividades de conhecimento. Ora, o que precisamente Guimarães Rosa almeja, através da narração de Riobaldo, é o domínio sobre uma realidade vivida em seus múltiplos aspectos. Esse domínio se reveste tanto de exposição como de reflexão, sendo que para ambas concorrem a memória, a intuição e a razão.

Em segundo lugar, de acordo com o que foi exposto no item 5, é na consciência subjetiva do personagem-narrador que se fecha a dialetização entre o histórico e o cultural, tomando este último em dois aspectos: um primeiro, mítico-religioso; um outro, de pensamento e reflexão crítica.

A interpretação de Sperber não se esquiva do abstracionismo, pois desconsidera a determinação que o sertão (em sua realidade e em sua travessia), exerce sobre a narração e a reflexão de Riobaldo. Esta determinação ocorre, tanto porque a vida sertaneja impõe ao jagunço o sofrível do seu meio físico, como, ao mesmo tempo, porque serve de sustentáculo a uma realidade simbólica expressa através da subjetividade do personagem-narrador. Isto significa que os preceitos expressos pelo Autor no trecho referido (8, p. 366), de nítida influência cristã, se impõem à interpretação, na medida em que são assegurados, tanto pela realidade do sertão, como pela necessidade de compreensão da travessia: uma travessia que narra e reflete o que Riobaldo viu e o que ele foi. Se se admite, rigorosamente, a interpretação de Sperber, dá-se relevância à impotência humana frente à força divina, fazendo imperar, com isso, a concepção religiosa sobre o vivido, como também sobre o anseio de entendimento racional de Riobaldo.

Resta, contudo, uma distância mínima entre a concepção platônica e o mito cristão da Criação. Para Platão, o mundo das idéias não pode ser alcançado pelo teatro, ao passo que o verdadeiro viver cristão pode ser atingido, e o exemplo desta possibilidade é tomado no teatro e na sua estruturação.

8. Outro eixo de discussão que se tira do trecho citado da página 366 , diz respeito ao poder do verbo que se faz ação; tanto para o ato divino da Criação, como para o ato humano do teatro. Ao mesmo tempo em que instaura o portador da palavra (Deus e o autor teatral) como a suprema autoridade da existência, também confere à palavra o poder de propulsionar a ação. A este propósito, em outra passagem, Guimarães Rosa manifesta-se da seguinte maneira:

“O que eu vi, sempre, é que toda ação principia mesmo é por uma palavra pensa-

da. Palavra pegante, dada ou guardada, que vai rompendo rumo”' $(8, \mathrm{p}, 137)$.

A importância conferida à palavra, tanto no ato divino dả Criação, como no humano do teatro, coloca o texto teatral como recurso que dá ao homem o mesmo poder de criar e estabelecer vidas. Assim, na figura do autor teatral, Criador e criatura se equiparam. Através do teatro, o homem reproduz a Criação. Ou é a Criação divina que é concebida a partir da prática de teatro! Disso resulta que, ou Deus deixa de ser superior e se iguala aos homens, ou o homem atinge os grạus da divindade.

Tanto um caso, como o outro, não podem ser tomados em si. Um substrato último 
resta como sustentáculo a esta aparente dualidade. Este substrato é exatamente o espaço e o exercício da história e da cultura. É numa determinada tradição histórica e no seu universo cultural correspondente que Deus tem o poder de conferir ou tirar vidas; é na prática artística, consagrada pela mesma tradição histórica, que o homem tem o poder de criar personagens e enredos.

O poder de Deus se dá, portanto, em uma prática histórico-cultural, através da conformação do imaginário social no decorrer dos tempos, vinculado a um particular anseio de entendimento da existência humana. Também o desejo humano de se igualar a Deus se dá no âmbito da história e da cultura, por intermédio de recursos de representação - no caso específico, teatro - que é produzido e reproduzido pelos homens, para produzir e reproduzir sentidos, no interior da sociedade e no seu universo simbólico. Deus e o teatro se encontram no fato de serem absolutos produtos de cultura, que são adotados pelos homens para ef eito de representação. Ainda assim, ocorre sensível perda para a entidade divina, pois, dos dois, somente o teatro encontra existência material. A única existência possível a Deus é como produto da relação do homem com o mundo na produção do universo cultural. O mesmo é aplicável ao diabo, como ressaltou Roberto Schwarz em seu livro, A sereia e o desconfiado:

"Nosso demônio, vimos, não tem existência material, é produto do contato dos homens com o mundo, e, não obstante, permanece insolúvel em psicologia ou fisiologia individuais; o modo de existir que resta é um só: cultural' (11, p. 46)

9. Contudo, o teatro não é apenas palavra que se torna ação. As ações podem não ter palavras; como pode, também, não ocorrer ação. E Guimarães Rosa concebe, por outro lado, o "teatral do mundo" por intermédio da ausência de palavras e de movimento:

“Seja ou não se aquele negócio entendessem, os companheiros aprovavam. Até Diadorim. Seja Zé Bebelo levantava a idéia maior, os prezados ditos, uma idéia tão comprida. O teatral do mundo: um de estadela, os outros ensinados calados', (8, p. 276)

O silêncio se dá em virtude do exercício de “estadela" de Zé Bebelo. Os demais, “ensinados calados". Esta situação é associada ao próprio espaço social destinado à representação teatral: a sala de espetáculos. Na platéia, os ouvintes calados, e, no palco, a ação. Naquele momento, Zé Bebelo e seus jagunços são a própria configuração do espaço e do espetáculo teatrais: relação entre um espaço ativo (ator: Zé Bebelo) e um passivo (público: jagunços).

Abstrai-se, da passagem acima, o próprio caráter de representação daqueles que apenas assistem, porque são componentes imprescindíveis do teatro. É o público que dá razão à interpretação; são os jagunços o endereçamento das idéias de Zé Bebelo. Com isso, Guimarães Rosa assegura ao teatro a participação do público - o que estende o espaço da representação para a totalidade do edifício teatral. Na passagem em que vem descrita a ação do Zé Bebelo e seus jagunços, o espaço é tomado como um todo, e é nesta unidade espacial (ação e recepção) que se configura o exercício da chefia e jagunçagem. Mais uma vez se identificam a vida e o teatro, desta feita na extrapolação dos espaços de cena e da vida. Na medida em que localiza e organiza a ação, a semelhança da cena rosiana com a disposição e atitude no teatro confere o grau mínimo de metaforização do teatro.

Já em outro momento, o teatral é tomado como um gesto sem palavra:

"Solei um vexame, por não saber a resposta concernente, nuns casos como esse 
BOLOGNESI, M.F. - Vida e teatro em Guimarães Rosa: Grande sertão veredas e Pirlimpsiquice.

Trans/Form/Ação, São Paulo, 8:49-60, 1985.

- resposta que eu achava que devia de ser uma só, e a justa, como em teatral em circo em pantomima bem levada. O que é igual quase um calar'’ (8, p.344).

Por esta passagem, pode-se alcançar os mínimos elementos indispensáveis à ocorrência do fenômeno teatral. São eles: o ator, o público e o texto. No caso do teatro sem palavras, o texto é considerado como sendo o enredo, a mensagem, ou o conteúdo. Desta maneira, vê-se que não há incoerência com o exposto no início do item 8 , a respeito do poder da palavra. Naquele contexto, coube ao verbo propulsionar uma ação; aqui, a ação não verbal se impõe. Resta, no entanto, para ambos os casos, a existência prévia de algo a transmitir: de uma idéia maior, para Zé Bebelo e seus companheiros; e de uma resposta única e justa, dada pelo silêncio, para o trecho último. Há um texto, uma mensagem anterior, matéria ainda informe, que precisa ganhar existência.

Uma vez identificados os elementos mínimos do teatro (texto, ator e público), identifica-se o ator como imagem virtual do homem em sociedade. Nos dizeres de Anatol Rosenfeld,

" O ator apenas executa de forma exemplar e radical o que é característica fundamental do homem: desempenhar papéis no palco do mundo, na vida social' (10, p. 31 ).

Se, para Guimarães Rosa, na vida cada um deve desempenhar com forte gosto seu papel, e se, ao mesmo tempo, é a atuação a imagem adequada para a exemplificação do verdadeiro viver, então conclui-se que o teatro e seus motivos são tomados em grau de identificação com a vida. Ou seja, para falar desta, reporta-se àqueles. E isso sem depositar qualquer conteúdo essencialista de perdas e danos. Em última instância, o teatro não é a exemplificação pauperizada da vida. Antes o contrário: das manifestações artístico-culturais o teatro é a que mais se adequa à comparação, na medida em que desnuda o exercício e a ação sociais, pela presença física e não mediada do ator com o público. O teatro é uma demonstração sintética, exemplar e radical do convívio social. Enquanto produto de cultura, ele tem o poder de representar a vida em sua totalidade. Representar não apenas no sentido fenomenológico do termo (tornar presente), mas, também, ao tornar presente, reconduzir o homem à prática de seu próprio universo de representação, substancialmente inserido em seu cotidiano, em sua existência. $\mathrm{O}$ teatro, acontecendo na história e na cultura, produz e reproduz os conteúdos sociais imanentes.

10. Se o teatro, por sua singularidade, é tomado como recurso privilegiado na exemplificação da vida, e se em Guimarães Rosa, tal como vem sendo visto, há identificação desses dois domínios, como, então, captar os limites de cada um? São eles idênticos em sua plenitude e totalidade?

No Grande sertão é admitida uma distância mínima entre um domínio e outro. Esta demarcação é identificável ao nível da terminologia, em virtude apenas do caráter metafórico que o teatro adquire: "Vida devia de ser como na sala de teatro..." (8, p. 187, grifos nossos). Para investigar com maior afinco os possíveis limites entre a vida e o teatro, seria necessário ao autor adentrar aos problemas e características propriamente teatrais - o que não acontece na narração de Riobaldo.

Entretanto, a distância e identificação da vida com a representação podem ser captadas no conto Pirlimpsiquice, do volume Primeiras estórias, posterior ao Grande sertão: veredas.

Em um internato, alguns alunos são escolhidos para participarem da encenação de uma peça. No entanto, para manterem, até o instante da estréia, o segredo do enredo, esses atores combinam a invenção de uma outra estória. Esta outra estória funda-se em 
fatos que normalmente ocorrem em seus cotidianos. Porém, há um espião nos ensaios que passa a revelar cenas da peça, da estória verdadeira, como é chamada. Imediatamente, um grupo de alunos, rival aos eleitos para o palco, começa a divulgar o enredo da peça, mesclando também dados de sua própria invenção. Com isso, uma outra versão passa a circular. Nesta relação triádica se instaura a discórdia entre os grupos. No jogo de revelar e esconder suas versões, o grupo de atores cada vez mais vai sendo tomado pela força da novidade e do impacto de sua estória (no conto denominada "nossa estória'), pois ela nasce do fascínio do segredo, da necessidade de invenção e do mistério pactário.

Chega o dia previsto para estréia. Momentos antes, entretanto, o aluno que interpretaria o papel principal é forçado a viajar, em virtude da morte de seu pai. A estréia seria sacrificada, não fosse a possibilidade de substituição do ator pelo ponto (no caso, o próprio narrador). Porém, o ponto, apesar de conhecer toda a trajetória e as falas da personagem, não havia decorado um poema inicial, de exaltação à Virgem e à Pátria, introduzido pelo diretor para dar início à representação. Diante de toda a platéia, ao invés da peça ter seu curso normal, previsto pelos ensaios, ocorre o silêncio constrangedor do ponto que não domina os versos adaptados ao espetáculo. A conseqüência do silêncio são as vaias de seus rivais.

Estaria fracassada a representação, não fosse a iniciativa de um dos meninos em dar início à improvisação da "nossa estória", mesclada com dados da “outra versão", a estória divulgada pelos rivais. Neste instante, “Zé Boné começou a representar" (9, p. 40). Sua representação tem um caráter único e irrepetível - é o drama do agora, inventado e vivível no dia-a-dia. Esta representação, uma vez iniciada, não tem mais final, e nela os meninos estão "transvivendo".

Como, porém, sair “do fio, do rio, da roda, do representar sem fim?” (9, p. 41). O narrador, ainda representando, e conscientemente, dá alguns passos adiante e cai do palco. A queda desponta, então, como revelação do espaço e do caráter de representação.

O conteúdo representado não é diferente do conteúdo vivido no cotidiano. No entanto, o momento do palco se constitui em representação - e não em vida, propriamente. Isso é possível, por intermédio da instauração de um espaço que se destina à representação. Neste espaço - o teatro - a vida passa a ser representação. Os limites são, portanto, produzidos unicamente pela prática social, no exercício da cultura. Se todo aquele improviso ocorresse normalmente, fora do espaço cênico, inserido em suas condições de alunos, ele não seria encarado como representação. $O$ ato consciente da queda revela a existência de um espaço onde há ação, e de um outro espaço onde se dá a recepção do espetáculo. Ao mesmo tempo, a queda demarca o limite e a ruptura do caráter de representação.

11. A especificidade de Guimarães Rosa no conto, iniciada com o Grande sertão: veredas, é justamente a de, ao estabelecer o limite de pura prática social, provocar, concomitantemente, a ruptura da distância entre vida e representação. A metáfora do teatro assume, pois, um grau mínimo de existência, conferido e legitimado apenas pela prática humana no exercício da cultura, uma vez que a fecundidade do desempenho no palco é tomada como equivalente ao desempenho na vida. Em Grande sertão: veredas, tem-se:

"Vida devia de ser como na sala do teatro, cada um inteiro fazendo com forte gosto seu papel, desempenho"' (8, p. 187); em Pirlimpsiquice: “Representar é 
aprender a viver além dos levianos sentimentos, na verdadeira dignidade' $(9, \mathrm{p}$. 35).

Com Pirlimpsiquice se esclarece o desempenho sincero e fecundo que Guimarães Rosa expressou no Grande sertão: veredas.

Ao promover a comparação da vida com o teatro, o autor não estabelece limites essencialistas de substituição do teatro pela vida. A ênfase dada situa-se exatamente no amalgamento dos domínios da história e da cultura, havendo inserção fecunda de uma na outra, e vice-versa. Não há vida sem teatro, e nem teatro sem a vida. É a essência que aparece; e a aparência que é essencial: é a representação (o teatro) que é vida; é a vida que é representação (teatro). A história só se manifesta na cultura, e esta, na história.

Para terminar, não é demais retomar a polêmica que Hegel estabelece com algumas visões platônicas acerca da arte e da sua prisão ao aparente. Diz ele, retomando o argumento de Platão:

“Dir-se-ia que a arte é o reino da aparência e da ilusão e que, portanto, àquilo a que chamamos belo se poderia também chamar aparente e ilusório’' (5, p. 91).

Em seguida, completa:

“Nada é mais certo: a arte cria aparências, e caso se considere a aparência como algo que não deve ser, concluir-se-á que a existência da arte é ilusória, que as criações artísticas são puras ilusões.

“Mas que é, no fundo, a aparência? Que relações tem ela com a essência? Não esqueçamos que, para não permanecer na pura abstração, toda a essência, toda a verdade, tem de aparecer. (...) a aparência não é inessente, pois, pelo contrário, constitui um momento essencial da essência'” (5, p. 91, grifos do autor).

É certo que a arte, por si só, não alcança - sequer almeja - o conhecimento da verdade. Mas também é correto afirmar que ela não é enganosidade e ilusionismo como pensou ser Platão, aqui recuperado através da sua formulação da alegoria da caverna. O âmbito da arte, por conseqüência, o do teatro, circunscreve-se nos domínios da história e da prática cultural. Fecha-se, portanto, no universo das representações. Este, por sua vez, mantém-se em constante dialetização com a vida, produzindo e reproduzindo sentidos que não podem ser considerados como falsidades. Se se produz visões distorcidas da realidade, nem por isso são elas falsas. São, isso sim, uma determinada visão do real, que se corresponde com um corpo ideológico específico e determinado (4). Portanto, o debate acerca do essencialismo e da aparência em si, desloca-se para o âmbito da obra em sua relação com a realidade, na fabricação de sentidos. Vaise, assim, do abstrato ao concreto; das idéias ao relacionamento histórico.

Esta parece ser a trajetória de Guimarães Rosa, ao menos no que diz respeito à adoção do teatro como expressão da vida - e vice-versa - , no modo como é empregada a metáfora do teatro na realidade do sertão, descrita, re-vivida e refletida pela narrativa. 
BOLOGNESI, M.F. - Vida e teatro em Guimarães Rosa: Grande sertão veredas e Pirlimpsiquice.

Trans/Form/Ação, São Paulo, 8:49-60, 1985.

BOLOGNESI, M. F. - Theater and lif aspects in Guimarães Rosa literature: Grande sertão: veredas and Pirlimpsiquice Trans/Form/Ação, São Paulo, 8:49-60, 1985.

ABSTRACT: This article is introduced with a summarized discussion on the "theater's metaphor" as considered by Plato. It goes on considering several turning points in the literature history and investigating the different uses of the metaphoric process in Guimarães Rosa "Grande sertão: veredas" and "Pirlimpsiquice". Firt of all, in "Grande sertão" life is considered as a simbolic equivalent to actors performance in the stage: theater and life are seen, therefore, as concerning fields which identities can be stated upon christian religious doctrine and Plotino's philosophy. On the other hand, in "Pirlimpsiquice', Guimarães Rosa points that the limits between life and theater fields can be sharply identified, leading to the conclusion that the different degrees of use of the metaphoric process is due to historical and cultural practices. Based on the theoric controversy between Hegel's and Plato's points of view on art's philosophy, the author concludes that the notions of "performance in the stage" and "performance in life" are sintetized under the continuous dialectic movement of history and culture.

KEY-WORDS: Literature; theater; theory of theater; Brazilian literature.

\section{NOTAS}

1. Para uma apreciação detalhada da metáfora do teatro, consultar: CURTIUS, E.R. - Metáforas teatrais. In: Literatura européia e Idade Média latina. Rio de Janeiro, INL, 1957. p. 144-150.

2. Grande sertão: veredas. 13. ed. Rio de Janeiro, J. Olympio, 1979. p. 9; 11; 12; 15 ; $20 ; 21 ; 33 ; 35 ; 40 ; 45-46 ; 49 ; 77 ; 108 ; 150 ; 169-170 ; 177 ; 187 ; 219 ; 229 ; 235 ; 271 ; 308$; $309 ; 319 ; 354 ; 355 ; 356 ; 358 ; 373 ; 387 ; 413 ; 433 ; 434 ; 460$.

3. A este respeito, consultar Calderón de La Barca. El gran teatro del mundo. 3. ed. Madrid, Aguilar, 1952. T. III, p. 203-223; BOAISTUAU, P. - Le théâtre du monde (1558). Genève, Droz, 1981.

4. Uma exposição minuciosa sobre o assunto é encontrada nas seguintes obras e autores: CHAUí, M. - O discurso competente; Crítica e ideologia. In: Cultura e democracia. São Paulo, Moderna, 1980. p. 3-38; LEFORT, C. - Esboço de uma gênese da ideologia nas sociedades modernas. Estudos $C E B R A P$, n. ${ }^{\circ}$ 10: 7-56, 1974.

\section{REFERÊNCIAS BIBLIOGRÁFICAS}

I. ANDRADE, A.M. - Universo, processo e ética no "Grande sertão: veredas" - uma análise do pensamento de Guimarães Rosa. Assis, Faculdade de Filosofia, Ciências e Letras, 1973. (Tese - doutoramento).

2. AUBENQUE, P. - Plotino e o neoplatonismo. In: CHÂTELET, F. - História da filosofia ịdéias, doutrinas. Rio de Janeiro, Zahar, 1973. v. I, p. 199-214.

3. CANDIDO, A. - O homem dos avessos. In: Tese e antitese. São Paulo, Nacional, 1978. p. 119-139.

4. COVIZZI, L.M. - O insólito em Guimarães Rosa e Borges. São Paulo, Ática, 1978.

5. HEGEL, G.W.F. - Estética: a idéia e o ideal. São Paulo, Abril Cultural, 1980.

6. MACHADO DE ASSIS, J.M. - Dom Casmurro. Rio de Janeiro, W.M. Jackson, 1946
7. PlATĀO - República. São Paulo, Difel, 1973.

8. ROSA, J.G. - Grande serıão: veredas. 13. ed. Rio de Janeiro, J. Olympio, 1979.

9. ROSA, J.G. - Pirlimpsiquice. In: Primeiras estórias. 12. ed. Rio de Janeiro, J. Olympio, 1981. p. 33-42.

10. ROSENFELD, A. - O fenômeno teatral. In: Texto/contexıo. São Paulo, Perspectiva, 1973. p. 21-43.

11. SCHWARZ, R. - Grande sertão: a fala; Grande sertão e Dr. Faustus. In:__ A Sereia e o desconfiado. Rio de Janeiro, Paz e Terra, 1981. p. 37-41; 43-51.

12. SPERBER, S.F. - Caos e cosmos - leituras de Guimarães Rosa. São Paulo, Duas Cidades; Secretaria da Cultura, Ciência e Tecnologia do Estado de São Paulo, 1976. 